\title{
The Tenth Justice Lost in Indian Country
}

\section{By Matthew L.M. Fletcher}

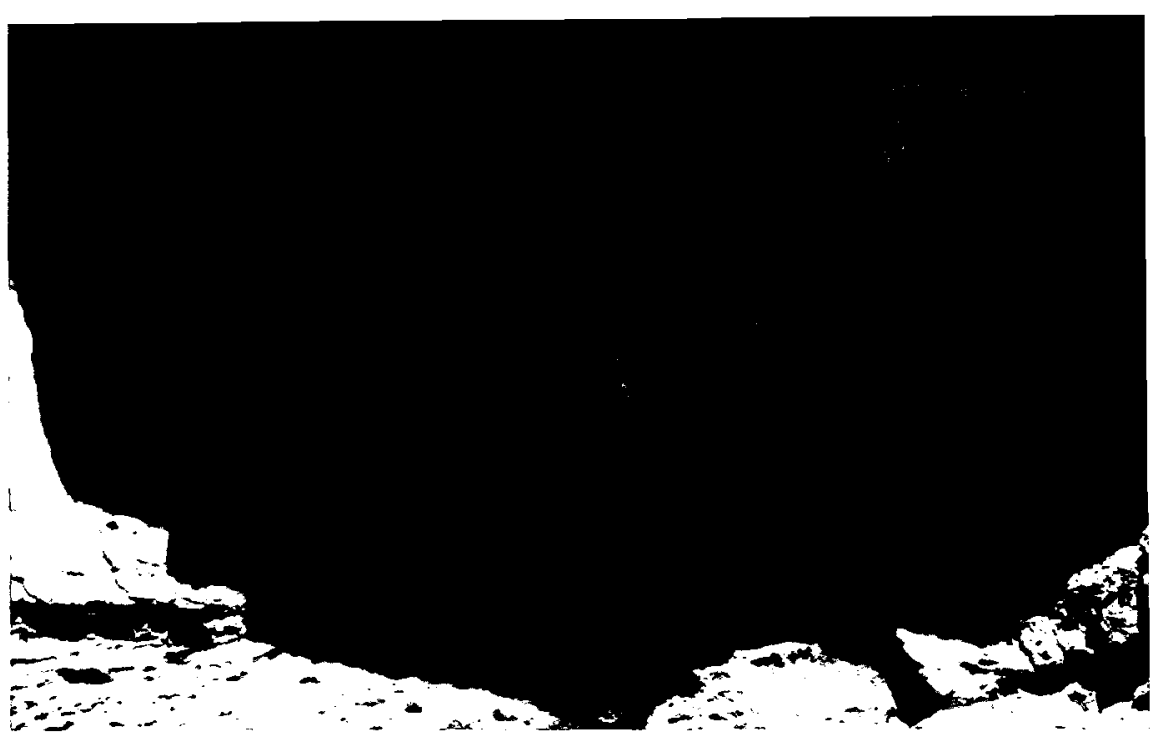

Photo: Petroglyphs, Delgadita Canyon, New Mexico. By Lawrence R. Baca.

We'd end up in Indian country. Out where nobody could even believe we were there. Places where you could get shot just for wearing corduroy. - Tom Waits ${ }^{1}$

The Office of the Solicitor General (OSG) occupies a special place in the jurisprudence and practice of the U.S. Supreme Court. The solicitor general, sometimes referred to as the "tenth justice," is the person that has the most influence with the Supreme Court but is not a sitting justice. The OSG's lawyers are among the best appellate litigators in the nation. Persuading the OSG to file an amicus brief favoring one's position may be the make-or-break moment in a case before the Supreme Court. ${ }^{3}$ Because the OSG represents the interests of the United States in every Supreme Court case involving the federal government, ${ }^{4}$ the office must file more than 100 briefs each term, making it by far the most repeat player in Supreme Court litigation. ${ }^{5}$

As a result, the outcomes of cases in which the OSG participates heavily favor the United States-beginning with the filing of a petition for certiorari to the final decision issued by the Court-as well as the parties aligned with the United States. The Court grants significant deference to the OSG on a wide variety of levels - both substantively and procedurally. Whereas the Court grants only about 3-5 percent of the petitions for certiorari filed in any given term, ${ }^{6}$ it grants 70 percent of these petitions filed by the OSG. ${ }^{7}$ And getting a case heard by the Court is more than half the battle, as the Court routinely grants cases with an eye toward reversing a lower court's ruling.

The kinds of cases involving the United States before the Supreme Court tend to favor the federal government. The OSG represents federal agencies that often are entitled to Chevron deference. The OSG represents the United States in federal criminal cases and defends federal statutes from constitutional challenges. In all these areas, the Court defers to the federal government.

None of this is new. Many other scholars have studied the OSG's success before the Supreme Court, but no one has studied the OSG's success when it serves in the unusual role as trustee for Indian tribes. The plain outcomes speak for themselves: the Supreme Court grants the Office of the Solicitor General almost no deference whatsoever when the OSG serves as trustee for Indian tribes or even when the government is simply on the same side as tribal interests. This trend is consistent with empirical research on the so-called continuum of deference, whereby federal courts appear to defer to certain federal agencies in nearly every case, while other agencies like the U.S. Department of Interior (which houses the Bureau of Indian Affairs) receives no deference at all, despite Chevron. ${ }^{8}$

This article presents results of a preliminary study of the OSG's performance at the Supreme Court from the 1998 through the 2009 terms. The discussion looks at the OSG's success rates before the Court at every stage of litigation beginning with the certiorari process and the Court's calls for the views of the solicitor general, as well as on the merits of the cases that reach final decision after oral argument.

The article begins with a review of the preliminary data on the OSG's success rate in Indian law cases. The data demonstrate that the OSG retains its success rate in both the certiorari process and on the merits when the United States is opposed to tribal interests. But when the OSG sits as a party alongside tribal interests-and especially when the OSG acts as an amicus siding with tribal interests-the OSG's success rate drops dramatically.

The second part of this article provides commentary on many of the Indian law petitions for certiorari and cases decided on the merits as well as the OSG's role in these instances. In Indian law cases not directly involving the interpretation of a federal statute (cases referred to as "common law" cases), the OSG often has to choose between two possible positions-whether to side with tribal interests or not to side with them. Usually, the OSG does side with tribal interests in common law cases. In Indian law cases directly involving the interpretation of a federal statute, the OSG's primary role is to defend the statute and the interpretation afforded the statute by federal agencies. In these cases, the OSG is on much stronger ground and often opposes tribal interests.

The purpose of this study is to help determine reasons for the very low success rate before the Supreme Court achieved by tribal interests in the past two or three decades. Taken in the greater context of other studies conducted on this phenomenon, the evidence that the 
Supreme Court has a significant and irrational animus against tribal interests is growing:

\section{The Data}

As shown in Figure 1, from the Court's 1998 term through its 2009 term, tribal interests prevailed in Supreme Court decisions on the merits six times and failed 19 times-a 27 percent success rate.

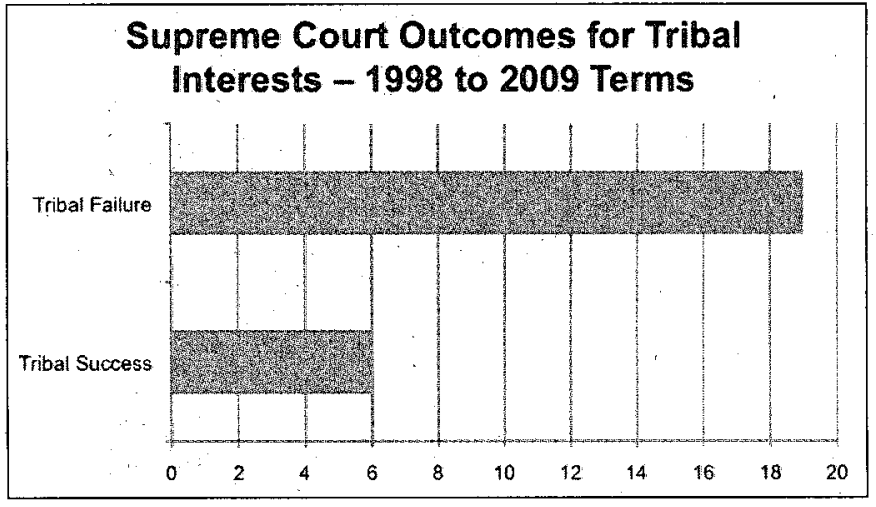

Figure 1

During the period studied, the United States sided against tribal interests six times in cases decided by the Supreme Court as either a party or as amicus, winning four times ( 67 percent). But the federal government also sided with tribal interests 13 times, prevailing a mere three times ( 23 percent). (See Figure 2.) In large part, the federal government's success rate during these 12 Court terms generally tracked the success rate of tribal interests. If the government opposed tribal interests, the government tended to succeed at its usual rate; but when the government sided with tribal interests, the government shared a very low success rate with tribal interests.



Figure 2

In the certiorari process, as a general rule, the OSG is successful in defending against petitions for certiorari filed against the United States or federal agencies, in contrast to tribal interests on both fronts. ${ }^{9}$ Rarely does a party succeed in convincing the Court to grant certiorari over the OSG's objections (only twice in 39 petitions during this period). Petitioners usually are successful only when the OSG acquiesces to a petition for certiorari. But when the OSG is defending such a petition brought against tribal interests, even if the United States is a party, the Supreme Court still grants more than 20 percent of the petitions ( 5 grants and 19 denials). (See Figure 3.)

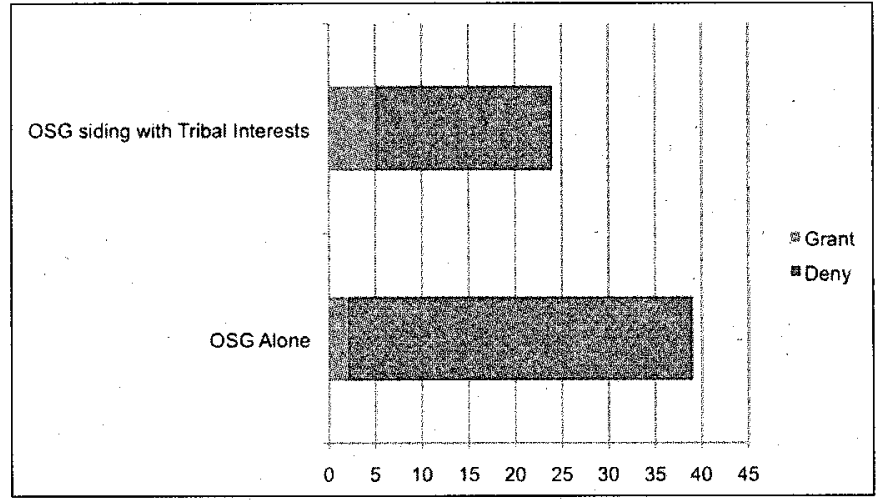

Figure 3

As a rule of thumb, it is always better for Supreme Court litigants to have the support of the United States and the OSG,$^{10}$ but for tribal interests, that support offers negligible advantages. To the extent that the Supreme Court defers to the OSG, the deference drops to virtually nothing when the OSG favors tribal interests. What's going on?

\section{The Cases}

Bare statistics tell only a portion of the story. It is useful to examine several cases in which the federal government participated. In general, the kinds of cases the Supreme Court decides in Indian law can be divided into two categories: federal common law and statutory interpretation cases. Criminal cases constitute a third category of cases that sometimes incorporate Indian law questions but usually involve only individual Indians.

\section{Federal Common Law Cases}

As a general rule, the Supreme Court has greater flexibility to decide federal common law questions. Indian law and admiralty law are really the only two subject areas in the U.S. Constitution that tend to involve questions of pure federal common law. In recent decadesduring the era of tribal self-determination-as Congress has increasingly left Indian tribes to their own devices, there have been fewer and fewer congressional acts that control the disputes that arise in Indian country. In addition, because more of the Indian law cases are common law cases, it appears from the outcomes reached by the Court in the past few decades that tribal interests fare exceptionally poorly in these cases. The sample studied here is consistent with that data.

\section{Land Claims}

Perhaps the Office of the Solicitor General's most astounding failure during the period under review came in cases involving Indian land claims. During the period, the Supreme Court decided the third in a line of cases involving the land claims of the Oneida Indian Nation: City of Sherrill v. Oneida Indian Nation of New York, 544 U.S. 197 (2005). The United States was not a party to this 
case, but in the prior two cases, the United States and the Oneida Indian Nation had been the plaintiffs in the land claims brought against the state of New York and various local governmental subdivisions. Oneida Indian Nation of N.Y. v. Oneida County, N.Y., 414 U.S. 661 (1974) (Oneida I); Oneida County, N.Y. v. Oneida Indian Nation of N.Y., 470 U.S. 226 (1985) (Oneida II).

The OSG and the tribe had been successful in two prior trips to the Supreme Court, establishing a federal common law cause of action to assert land claims in the first case and winning on the merits of the land claims in the second case. Importantly, even though the Court did not decide the question because the state had waived it, a majority of the Oneida II Court would have rejected equitable defenses to the land claims, including laches, acquiescence, and impossibility. See Oneida II, 470 U.S. at $244-45$ \& n.16; $i d$. at 256 (Stevens, J., dissenting).

Sherrill involved the reacquisition of the land in fee by the Oneida Indian Nation within its reservation's boundaries. Under common law principles of federal Indian law, the Treaty of Canadaigua, and the federal Trade and Intercourse Act, the Oneida Nation asserted that it was not required to pay property taxes to the local jurisdictions for this land. The Second Circuit agreed with the Oneida Nation on this theory, and the city of Sherrill sought certiorari to review the decision. The United States was not a party to the lower court's proceedings, but the conference requested the solicitor general's views. The OSG opined that the petition should be denied, but the Court granted certiorari anyway. The OSG participated as amicus and split time during oral argument with the Oneida Nation's counsel, but the Court ruled against the Oneida Nation on the merits. Incredibly, the Court ignored the underlying legal theories altogether and, instead decided against the Oneida Nation on grounds raised only by amici supporting the petitioner-the equitable defenses of laches, acquiescence, and impossibility. "Even more incredibly, the Court applied those defenses not to the Oneida Nation, but to the United States itself. The Court's broad language strongly implied that these equitable defenses would henceforth apply to any Indian claim not directly tied to Indian treaty rights.

Shortly after the Court issued the Sherrill decision, the Second Circuit dismissed the entire bevy of land claims asserted by the Cayuga Indian Nation of New York-a tribe similarly situated as the Oneida Indian Nation was and that had long relied on the same legal theories that had been successful for the Oneidas. 413 F.3d 266 (2d Cir. 2005). The United States, already a party to the Cayuga Indian Nation's land claims, brought a petition for certiorari. The Court denied the petition without comment. United States v. Pataki, 547 U.S. 1128 (2006) (No. 05-978); Cayuga Indian Nation of N.Y. v. Pataki, 547 U.S. 1128 (2006) (No. 05-982).

The New York land claims cases are the most remarkable instances in which the interests of the United States, coinciding with tribal interests, failed spectacularly before the Supreme Court. Usually, in cases involving tribal interests when the federal government sides with the tribes, it is the tribal interests that have the most to lose. But in the New York land claims cases, the United States lost on the question of whether common law equitable defenses could be used to defeat the property interests of the federal government. This was a very significant strategic loss for the Office of the Solicitor General.

\section{Taxation Cases}

Even more so than land claims, cases involving taxation of Indian tribes are rooted in federal common law. Long ago, the Supreme Court adopted a rule that states and local governments cannot tax tribal property or transactions without an authorizing act of Congress. In re Kansas Indians, 72 U.S. 737 (1866). However, Congress rarely has expressed with any clarity when tribal property and transactions become taxable by states and localities. So what constitutes authorizing legislation is for the Court to decide as a matter of federal common law

During the period studied, the OSG filed briefs on the merits in several Indian taxation cases. In two important cases, the OSG sided with tribal interests and shared oral argument time with tribal lawyers. And, in these cases, the Supreme Court rejected the OSG's position. Only in the cases in which the OSG opposed tribal interests did the Court agree with the federal position. In short, the Supreme Court agrees with the OSG in Indian taxation cases only when the OSG opposes tribal interests.

In these cases, the federal government has less of a stake than it has in the land claims cases. The United States is usually not a party to taxation cases, nor is there a significant federal interest at stake. Here, the OSG is acting in the government's role as the trustee for Indian tribes. However, in cases in which the government opposes tribes, the impetus is the government's interest in the proper interpretation of a federal statute.

The cases in which the OSG participated as amicus favoring the tribal interests-Atkinson Trading Co. Inc. $v$. Shirley and Wagnon v. Prairie Band Potawatomi Nationboth involved the tribal interests as the respondent. In both cases, a state government opposed the tribes and the Office of the Solicitor General. 532 U.S. 645 (2001); 546 U.S. 95 (2005). In Atkinson Trading, Texas participated as an amicus and shared oral argument time, and in Wagnon, Kansas was the petitioner. The participation of these states surely offset whatever deference the Supreme Court would offer the OSG.

In contrast, the Supreme Court followed the OSG's reasoning in Arizona Dept. of Revenue v. Blaze Construction, another case in which the OSG shared oral argument time. 526 U.S. 32 (1999). In that case, the OSG sided with the state of Arizona in arguing that the respondent should be subject to state taxation for extraction of natural resources found on the reservation.

Finally in Cbickasaw Nation v. United States, the OSG successfully argued that the Indian Gaming Regulatory Act did not exempt tribal gaming operations from certain federal taxes. 534 U.S. 84 (2001). In the statute in question, Congress had offered a list of exempted activities that supported the Chickasaw Nation's position, but the Supreme 
Court interpreted the statute to exclude the plain language on grounds that Congress had made a mistake.

\section{Tribal Court Jurisdiction Cases}

Despite the support of the OSG in several cases, tribal interests have never persuaded the Supreme Court in any specific case that nonmembers can be subject to the regulatory or adjudicatory authority of the tribe. Even more than taxation cases, these cases are explicitly questions of federal common law with nary an act of Congress applicable. See generally National Farmers Union Ins. Cos. $v$. Crow Tribe of Indians, 471 U.S. 845 (1985); Iowa Mutual Ins. Co. v. Laplante, 480 U.S. 9 (1987).

One of the more devastating cases for tribal advocates in the period under review was Nevada v. Hicks, 533 U.S. 353 (2001). That case involved Floyd Hicks, a tribal citizen, and a state game warden who twice went into Indian country to execute search warrants for evidence that a tribal citizen had captured an endangered species. In the first instance, the state officer domesticated his state courtissued search warrant with the tribal court and sought assistance from tribal police, but in the second instance he did not. The state officer found nothing both times, and Floyd Hicks sued the officer in tribal court under federal civil rights statutes for the damage done to his home. Before the Supreme Court, the OSG shared oral argument time with Hicks' advocate, but the Supreme Court roundly rejected their claims, holding that the tribal court could never have jurisdiction over a state officer, and that tribal courts cannot have jurisdiction over any claims brought under federal civil rights statutes.

In 2008, the Supreme Court decided Plains Commerce Bank v. Long Family Land \& Cattle Co., 128 S. Ct. 2709 (2008). Once again, the OSG participated as amicus favoring the tribal interests and shared oral argument time, this time arguing that the federal government's practice of guaranteeing loans to tribal businesses provided a sufficient federal interest to favor tribal court jurisdiction over a non-Indian-owned bank that had foreclosed on Indian lands. And once again, the Supreme Court gave short shrift to the OSG, although the 5-4 outcome (Justice Souter joined the dissenters) was much closer.

\section{Other Common Law Cases}

During the period studied, the Supreme Court decided one case involving the sovereign immunity of Indian tribes: $C \&$ L Enterprises v. Citizen Potawatomi Nation, 532 U.S. 411 (2001). Even with the OSG sharing oral argument time with the tribal nation, the Supreme Court held that the tribe had implicitly waived its immunity from suit in state court.

In addition, in Rice $v$. Cayetano, a case involving Native Hawai'ian interests, the Supreme Court invoked the Fifteenth Amendment to hold that non-Native Hawai'ians can vote in elections and become trustees for the Office of Hawai'ian Affairs, which administers the property rights of Native Hawai'ians. 528 U.S. 495 (2000). The OSG shared oral argument time with the Native Hawai'ian advocates, but the Supreme Court ruled 7-2 against them. In 2009, the Court again rejected the claims of Native Hawai'ians in Hawai' $i v$. Office of Hawai'ian Affairs but at least remanded the case to the Hawai'ian Supreme Court to reconsider under state law. 129 S. Ct. 1436 (2009).

\section{Statutory Interpretation Cases}

In Indian law cases in which the main issue in question is the interpretation of a federal statute, the United States often vacates its position as trustee for tribal interests in favor of its more important position of defending the constitutionality or agency interpretation of the statute. But in this different role before the Supreme Court, the OSG's success rate continues to track the success rate of the tribal interest at stake.

Consider Amoco Production Co. v. Southern Ute Indian Tribe, in which the United States shared oral argument time with the tribal respondent but argued for a more neutral interpretation of the statutes in question, the Coal Lands Acts of 1909 and 1910. 526 U.S. 865 (1999). Even in that case, the Court rejected much of the government's position, with some justices openly laughing at the government's advocate.

Another major blow to both the United States and its tribal trustees was Dept. of Interior $v$. Klamath Water Users Protective Ass'n., 532 U.S. 1 (2001), in which the government and the Klamath Tribe in Oregon had shared documents prepared in anticipation of litigation over the Klamath River's limited water resources. Opponents of the tribe sought to obtain those documents through the Freedom of Information Act, and the government rejected the claim because they had been prepared for litigation purposes. The Supreme Court broadly interpreted the act and narrowly construed the trust relationship between the government and tribes to reject the government's reasoning.

Perhaps the most disruptive recent case is Carcieri v. Salazar, in which the Supreme Court held that the Department of Interior cannot take land into trust for Indian tribes that were not "under federal supervision" in 1934. 129 S. Ct. 1058 (2009). In this case, the OSG argued strenuously in favor of the Interior Department's 70-plusyear interpretation of the Indian Reorganization Act, the federal government's position as trustee for Indian tribes, and the historical purposes of the act, only to be bluntly rejected by the Supreme Court by a vote of $8-1$. The decision may place the future land acquisitions of perhaps as many as 100 tribes at risk.

Another major loss for the federal government, but this time favoring tribal interests, was Cherokee Nation $v$. Leavitt, 543 U.S. 631 (2005). In its decision in this case, the Supreme Court held 8-0 that the Indian Self-Determination and Education Assistance Act required the U.S. Department of Health and Human Services to pay contract support costs to tribal government Indian health contractors, even if Congress had not been appropriated the money. In that case, numerous non-Indian-related federal contractors sided with the tribes as amici and argued that the federal government had been denying them contract support costs as well perhaps tipping the scales in favor of the tribal contractors. 
When the United States sides against tribal interests in a statutory interpretation case, the OSG's success rate returns to normal. A case in point is Inyo County, Cal. v. PaiuteShoshone Indians, in which the OSG argued as amicus in a case involving the county officials' forced entry onto the tribal gaming complex to look for employment records. 538 U.S. 701 (2003). The OSG argued that the Bishop Community was not eligible to sue under federal civil rights statutes, a position with which the Court agreed, but argued that tribal sovereign immunity shielded the tribe from the imposition of the county officials, a position of which the Court seemed extremely skeptical but remanded for further consideration.

A complex type of statutory interpretation case that involves significant common law principles is the so-called trust case. These are cases usually brought by tribal interests against the federal government for failure to comply with a federal statute or treaty benefiting tribal interests. The Court decided three of these cases during the period studied, ruling in favor of the United States in two of them, with a major trust case-Cobell $v$. Salazar-hovering in the lower courts. It is typical that the Supreme Court will only hear these kinds of cases when the United States loses in lower courts and petitions for review. The Court does not hear tribal petitions and refused to hear two Cobell petitions brought by tribal interests. Cobell $v$. Kempthorne, 549 U.S. 1317 (2007) (No. 06-867); Cobell v. Kemptborne, 549 U.S. 1317 (2007) (No. 06-868). The case has since been settled.

In 2003, the Supreme Court decided two cases on the same day: United States $v$. Navajo Nation and United States v. White Mountain Apache Tribe, 537 U.S. 488 (2003); 537 U.S. 465 (2003). White Mountain involved the federal government's failure to maintain government buildings before turning them over to the tribe. The Court held that the government breached its fiduciary duty to the tribe because a federal statute had guaranteed the properties to the tribe after the United States ceased to use them, affirming a judgment of several million dollars made by a lower court.

In Navajo Nation, the secretary of the interior had met in secret with a representative of Peabody Coal, who advocated in favor of dramatically reducing royalties owed to the Navajo Nation. The secretary then ordered that lowerlevel agency officials' approval of a higher royalty rate be reconsidered, which led to the approval of a significantly lower rate that benefited the coal company. The Federal Circuit had affirmed a $\$ 600$ million judgment against the government for breach of trust, and the Supreme Court reversed the ruling, finding no duty at all to the Navajo Nation. In 2009, after the Federal Circuit once again held in favor of the Navajo Nation on a different theory, the Supreme Court unanimously reversed the ruling. United States v. Navajo Nation, 129 S. Ct. 1547 (2009).

\section{Treaty Rights}

In the last several decades, tribal interests have often failed before the Supreme Court in most common law questions, but the tribes have been relatively successful in preserving their treaty rights. Typically in treaty rights cases, the United States is an interested party or at the very least an amicus in favor the tribal signatory to the treaty because the treaty in question usually is being challenged by a state government. The main case in point during the period studied is Minnesota $v$. Mille Lacs Band of Chippewa Indians, and once again the OSG shared oral argument time with the tribal advocate. 526 U.S. 172 (1999).

Mille Lacs involved the interpretation of an 1837 treaty, which specifically reserved hunting and fishing rights for the Indians, and whether an executive order from 1850 and a second treaty from 1855 had abrogated those rights. Because the 1855 treaty did not mention those rights, the Court held that it did not specifically abrogate them. But the 1850 executive order purported to abrogate those rights. A narrow 5-4 majority held that the President could not abrogate the 1837 treaty unilaterally. In a similar case, Arizona $v$. California, the United States and the Quechan Tribe joined to persuade the Court that the federal government could bring claims for increased water rights on behalf of the tribe. The Court ruled for the tribe by a vote of 6-3. 530 U.S. 292 (2000). Finally, while not technically a treaty rights claim, in Idabo $v$. United States, the OSG successfully argued that an 1873 executive order and an 1891 act of Congress preserved the Coeur d'Alene Tribe's rights to submerged lands in Lake Coeur d'Alene. 533 U.S. 282 (2001).

These treaty rights claims all involved $19^{\text {th }}$ century arm's length transactions between the United States and Indian tribes that state governments challenged more than 100 years later. The OSG's success rate reflects the federal government's interest, perhaps, in preserving these longstanding agreements with Indian tribes.

\section{Criminal Law}

Unlike the 1960s, 1970s, and 1980s, when the Supreme Court decided numerous criminal cases involving federal, tribal, and state criminal jurisdiction in Indian country, between 1998 and 2009, the Court reviewed only one criminal case involving Indian law: United States $v$. Lara. 541 U.S. 193 (2004). It is likely that the case caught the Court's attention because it involved an act of Congress designed to overrule a Supreme Court common law decision from 1990: Duro v. Reina, 495 U.S. 676 (1990). The statute, known as the Duro Fix, restored tribal criminal jurisdiction over a class of persons known as "nonmember Indians"-Indian persons who are citizens of an Indian tribe but not members of the tribe prosecuting them. After a decade of operation, a circuit split developed over whether Congress had authority to reverse the Supreme Court's decision that Indian tribes cannot have criminal jurisdiction over nonmembers of the tribe.

The OSG prevailed in Lara but took advantage of the slightly unusual procedural posture of the case-a position that potentially would have been ruinous to tribal interests. Billy Jo Lara, a member of the Turtle Mountain Band of Chippewa Indians, had been prosecuted in tribal court for punching a Bureau of Indian Affairs police officer who had been cross-deputized by the Spirit Lake Tribe (the equiva- 
lent of punching two sovereigns in the face). Only later did the U.S. attorney bring charges for assaulting a federal officer. Lara successfully argued before the Eighth Circuit that the Spirit Lake Tribe's prosecution was valid only as a delegation of federal authority (which was surely not the intent of Congress, but the only way the Eighth Circuit could see to uphold the Duro Fix statute), rendering the subsequent federal prosecution a violation of the Double Jeopardy Clause.

The OSG argued before the Supreme Court that Congress had full authority to overrule a federal common law decision, but argued in the alternative that the Spirit Lake Tribe's prosecution of Lara was invalid, preserving the federal prosecution either way. The strategy of Lara's counsel, which was completely caught up in this conundrum and by the fact that Lara had not appealed his conviction by a tribal court to federal court, as he could have done under the Indian Civil Rights Act, collapsed during oral argument. But the OSG's primary position won the votes of only Justices Breyer, Stevens, O'Connor, and Ginsburg, as well as Chief Justice Rehnquist, and only three of those justices remain on the Court today. The OSG's alternative position persuaded at least two justices-Kennedy and Thomas-and Justices Souter and Scalia dissented on grounds that the Duro Fix statute was unconstitutional. The Lara decision, hailed as a strong 7-2 precedent in favor of tribal and federal interests, is a somewhat weaker precedent, with two sitting justices in favor, three against, and four undecided (Chief Justice Roberts and Justices Alito, Sotomayor, and Kagan).

However, in two petitions brought in the 2005 term, the Supreme Court denied certiorari in cases that were direct appeals of tribal court jurisdiction over nonmember Indians, perhaps granting deference to U.S. interest in legislating for criminal jurisdiction in Indian country. Morris v. Tanner, 549 U.S. 970 (2006) (No. 05-1285); Means v. Navajo Nation, 549 U.S. 952 (2006) (No. 05-1614).

\section{Conclusions?}

The success the Office of the Solicitor General has enjoyed in opposing tribal interests remains unabated, and already this term the Supreme Court has granted two petitions brought by the United States against Indian tribes: United States $v$. Tohono O'Odham Nation and United States v. Jicarilla Apache Tribe, 559 F.3d 1284 (Fed. Cir. 2010), cert. granted, 130 S. Ct. 2097 (2011); In re United States, 590 F.3d 1305 (Fed. Cir. 2010), cert. granted, 131 S. Ct. 856 (2011). Interestingly, three times this term the Court has asked the OSG for its views on petitions for certiorari involving state governments opposing tribal interests. In Hogan v. Kaltag Tribal Council, the Court agreed with the OSG's recommendation and denied the state of Alaska's petition for certiorari. 131 S. Ct. 66 (2011). And in Thunderborse $v$. Pierce, the Court again agreed with the OSG in denying an American Indian prisoner's petition against Texas, despite the likelihood that the lower court applied the incorrect legal standard in a case involving religious freedom. 131 S. Ct. 896 (2011). Two other invitation briefs are pending at this writing. See Schwarzeneggar v. Rincon
Band of Luiseño Mission Indians of the Rincon Reservation (No. 10-330) and Osage Nation v. Irby (10-537).

There are no clear answers to why tribal interests have fared so poorly before the U.S. Supreme Court since the 1980s. A decade ago, Dean David Getches wrote that convicted criminals have a better success rate on the merits than do Indian tribes and other tribal interests. ${ }^{12}$ Even less clear is why the Office of the Solicitor General has such a difficult time in cases involving Indian country, especially given that the federal government has a treaty- and statutebased trust relationship with Indian tribes. What is certain is that the OSG will continue to play an enormous role in Indian affairs. TFL

Matthew L.M. Fletcher is an associate professor at Michigan State University College of Law. This article reports preliminary data of a larger study of the success of the solicitor general in Supreme Court adjudication involving civil rights, Indian law, and federalism cases since the Court's 1998 term. (C) 2011 Matthew L.M. Fletcher. All rights reserved.

\section{Endnotes}

${ }^{1}$ Elizabeth Gilbert, Play It Like Your Hair's on Fire, G.Q. 248, 254 (June 2002).

${ }^{2}$ L.C. Caplan, The Tenth Justice: The Solicitor General and THE Rule OF LAw (1987).

${ }^{3}$ See Patricia A. Millett, "We're Your Government, and We're Here to Help": Obtaining Amicus Support from the Federal Government in Supreme Court Cases, $10 \mathrm{~J}$. App. Pract. AND Process 210 (2009).

${ }^{4}$ See Susan Low Bloch et al., Inside the Supreme Court: The Institution and Its Procedures 824-25 (2d ed. 2008); Kevin T. McGuire, Explaining Executive Success in the U.S. Supreme Court, 51 PoL. Res. Q. 505, 506 (1998) ("virtually the sole representative of the United States in the Supreme Court").

${ }^{5} \mathrm{Cf}$. Mark Galanter, Why the "Haves" Come Out Abead: Speculations on the Limits of Legal Change, 9 Law \& Soc'y REv. 95 (1974) (introducing the theory that "repeat players" have a greater chance to succeed in any given lawsuit).

${ }^{6}$ Lee Epstein et al., The Supreme Court Compendum: Data, Decisions, and Developments 75 (4th ed. 2007).

${ }^{7}$ Rebecca Mae Salokar, The Solicitor General: The Politics of Law, in Bloch et al., supra note 4, at 835, 836.

${ }^{8}$ See William N. Eskridge and Lauren E. Baer, The Continuum of Deference: Supreme Court Treatment of Agency Statutory Interpretations from Chevron to Hamdan, 96 GEo. L.J. 1083, 1137-38 (2008).

${ }^{9}$ See generally Matthew L.M. Fletcher, Factbound and Splitless: The Certiorari Process as a Barrier to Justice for Indian Tribes, 51 ARIz. L. Rev. 933 (2009).

${ }^{10}$ The success rate of the United States as amicus curiae before the Supreme Court is impressive. See Epstein et al.,

\section{TENTH JUSTICE continued on page 58}


${ }^{16} \mathrm{Chew}$ and Kelley, Myth of the Color-Blind Judge, supra note 3 , at 1117,1141 (citation omitted).

${ }^{17} I d$. at 1156.

${ }^{18}$ Kevin K. Washburn, Keynote Address: The Next Great Generation of American Indian Law Judges, 81 U. Colo. L. Rev. 959 (Fall 2010) ("The central challenge in Indian law is ensuring that Indian law and Indian tribes are not some alien concept, but are a regular part of the cultural and governmental background in the United States.").

${ }^{19} \mathrm{Id}$. at 963 . In particular, Dean Washburn points to the increased understanding of federal Indian law as demonstrated by the decisions of U.S. Supreme Court Chief Justice John Marshall, Justice Stevens, Justice O'Connor, and Justice Ginsberg.

${ }^{20} \mathrm{Id}$.

${ }^{21}$ Heather Kendall-Miller Noted for Ninth Circuit Spot (July 26, 2010); available at turtletalk.wordpress.com.

${ }^{22}$ National Congress of American Indians, Support for the Nomination and Confirmation of Heather Kendall-Miller to the United States Court of Appeals for the Ninth Circuit, Resolution \#ABQ-10-019 (Nov. 14-19, 2010). In notable part, the resolution indicates that the National Congress of American Indians supports Heather Kendall-Miller's nomination and confirmation because "over the course of U.S. history the federal judiciary has established principles of respect for tribal self-government and deference to the political branches and intergovernmental comity in determining the course of the federal-tribal relationship and the scope of recognized tribal authority; and ... the federal judiciary is regularly tasked with making deci- sions that have a lasting impact on tribal communities and the daily lives of Indian people, including decisions regarding tribal sovereignty, public safety and health on Indian reservations, tribal economic development, generation of tax revenue, and protection of tribal cultures and religions; and ... the U.S. has never appointed a Native American to the federal appellate bench or the Supreme Court, and out of the total 866 federal judgeships, not one is currently occupied by and American Indian or Alaska Native...."

${ }^{23}$ Keith Harper for the Tenth Circuit Drawing Intense Opposition (May 23, 2010); available at turtletalk.word press.com.

${ }^{24} \mathrm{Id}$.

${ }^{25}$ Cherokee Nation, Council Passes Resolution to Support Harper for U.S. Appeals Court (June 30, 2010); available at www.cherokee.org/NewsRoom/FullStory/ 3266/Page/Default.aspx.

${ }^{26}$ Executive Office of the President, Office of the Press Secretary, President Obama Names Two to the United States District Court (Feb. 2, 2011); available at www.whitehouse.gov/the-press-office/2011/02/02/ president-obama-names-two-united-states-district-court.

${ }^{27} \mathrm{Id}$.

${ }^{28} \mathrm{Chris}$ Casteel, President Nominates Federal Prosecutor to be U.S. Judge in Tulsa, NewsOK.com (Feb. 3, 2011); available at newsok.com/president-nominatesfederal-prosecutor-to-be-u.s.-judge-in-tulsaarticle/353 7611\#ixzz1D1KCYYfi.

${ }^{29} \mathrm{Id}$. 1430 .

\section{TENTH JUSTICE continued from page 41}

supra note 6, at 691.

${ }^{11}$ See Kathryn E. Fort, The New Laches: Creating Title Where None Existed, 16 Geo. Mason L. Rev. 357 (2009).

${ }^{12}$ David H. Getches, Beyond Indian Law: The Rebnquist Court's Pursuit of States' Rights, Colorblind Justice and Mainstream Values, 86 MinN. L. Rev. 267, 280-81 (2001) ("Tribal interests have lost about 77 percent of all the Indian cases decided by the Rehnquist Court in its fifteen terms, and 82 percent of the cases decided by the Supreme Court in the last ten terms. This dismal track record stands in contrast to the record tribal interests chalked up in the Burger years, when they won 58 percent of their Supreme Court cases.") (footnotes omitted).

\section{FEDERAL TRUST continued from page 57}

Court heard, considered, and rejected these arguments by the government in [White Mountain] Apache"), rev'd on other grounds, 129 S. Ct. 1547 (2009); Cobell v. Norton, 392 F.2d 461, 472 (D.C. Cir. 2004) (under White Mountain Apache, "once a statutory obligation is identified, the court may look to common law trust principals to particularize that obligation"); Cobell $v$. Norton, 240 F.3d 1081, 1100-01 (D.C. Cir. 2001) (per Mitchell II, "[t]he general 'contours' of the government's obligations may be defined by statute, but the interstices must be filled in through reference to general trust law"); Duncan $v$. United States, 667
F.2d 36, 42-43 (Ct. Cl. 1981) (rejecting that "a federal trust must spell out specifically all the trust duties of the Government"); Navajo Tribe, 624 F.2d at 988 ("Nor is the court required to find all the fiduciary obligations it may enforce within the express terms of an authorizing statute. ...").

${ }^{10}$ See Remarks by President at White House Tribal Nations Conference (Dec. 16, 2010) ("I want to be clear: What matters far more than words ... are actions to match those words. ... That's the standard I expect my administration to be held to."). 